\title{
Dialysis-associated steal syndrome with limb ischaemia
}

\author{
Dimitrios Karavias, ${ }^{1}$ Ioannis Tsolakis, ${ }^{2}$ Spyros Papadoulas ${ }^{2}$
}

'Department of Hepatobiliary and Pancreatic Surgery, Queen's Medical Centre, Nottingham, UK ${ }^{2}$ Department of Vascular Surgery, University of Patras School of Medicine, Patras, Greece

\section{Correspondence to} Dr Dimitrios Karavias, dimitriskaravias@gmail.com

Accepted 16 July 2017

\section{DESCRIPTION}

A 62-year-old man with end-stage renal failure on dialysis was referred to our hospital with worsening pain and ulceration in his right arm. $\mathrm{He}$ was started on haemodialysis 6 months ago, once his newly created brachiocephalic fistula was matured. Previously, he had been on peritoneal dialysis for over 2 years and was transitioned to haemodialysis after multiple catheter-site infections and peritonitis. His medical history was significant for poorly controlled hypertension and hypercholesterolaemia. On physical examination, necrosis of the skin and subcutaneous tissue localised to the right forearm and hand was evident (figure 1), along with dry gangrene of the fourth digit (figure 2). Right radial and ulnar artery pulses were absent. The arm distal to the fistula was cool, with decreased capillary refill and decreased sensation. Continuous handheld Doppler revealed exceptionally low radial and ulnar artery pulse signals and absence of flow at the digital arteries. Compression of the fistula at the anastomosis site was accompanied with pulse return distally and pain relief. Duplex ultrasound examination revealed a patent vascular

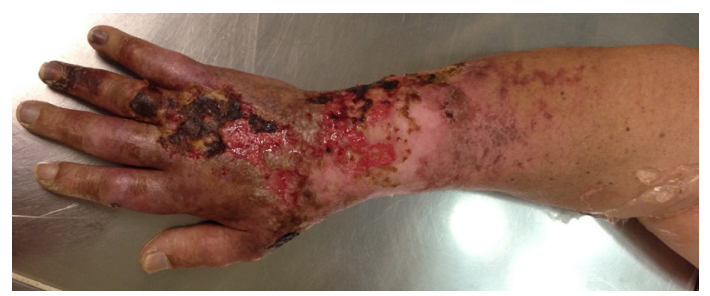

Figure 1 Necrosis of the skin and subcutaneous tissue localised to the right forearm and hand.

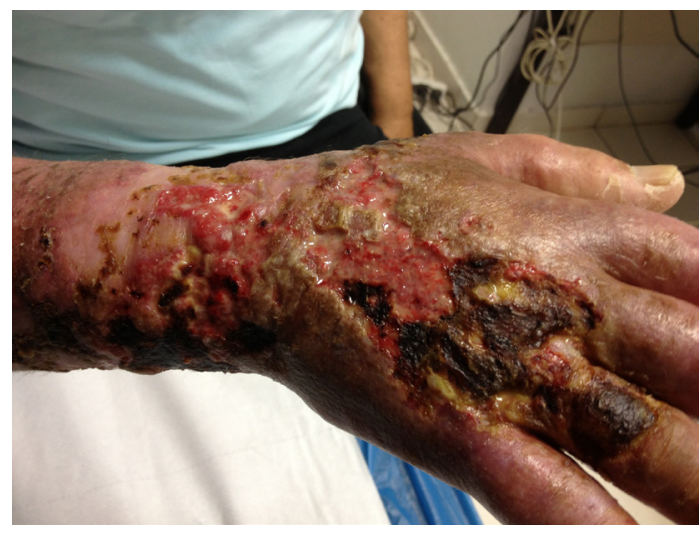

Figure 2 Ulceration of the right hand along with dry gangrene of the fourth digit.

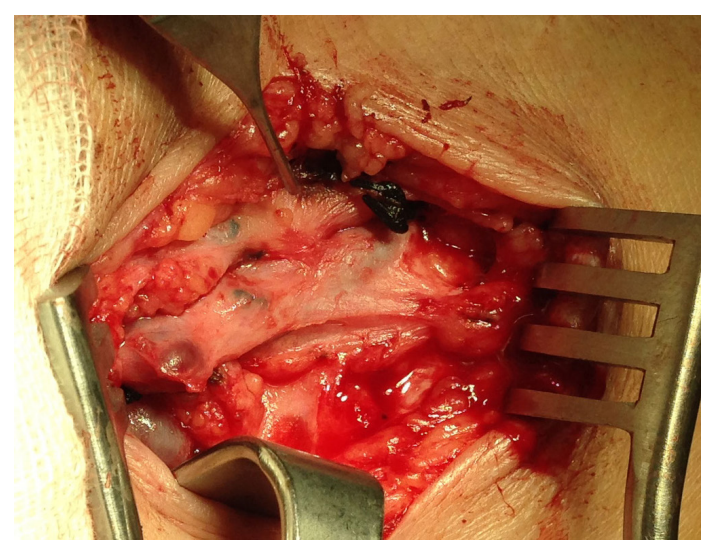

Figure 3 Intraoperative image of the arteriovenous fistula prior to ligation.

Learning points

- Decreased arterial blood flow distal to an arteriovenous fistula is common during dialysis and most patients only experience intermittent pain and numbness.

- Dialysis associated ischaemic steal syndrome is uncommon and typically presents with limb ischaemia accompanied with pain, motor and sensory deficits.

- Early diagnosis with duplex ultrasonography and treatment with radiological or surgical intervention are essential to prevent permanent damage.

access with no arterial obstruction. A clinical diagnosis of dialysis-associated steal syndrome was made. To prevent irreversible injury to the affected limb, revision surgery aiming to treat the steal syndrome maintaining the patency of the vascular access was not attempted. In an otherwise potentially infected field, the fistula was urgently ligated and the patient was treated with antibiotics, with alleviation of the symptoms (figure 3 ).

Decreased arterial blood flow distal to an arteriovenous fistula is a common physiological phenomenon. ${ }^{1}$ Most patients are asymptomatic and only a small number of patients experience intermittent pain and numbness during dialysis. ${ }^{2}$ On the contrary, patients with severe pain, coldness, pallor or ulceration of the limb and severe ischaemia with motor and sensory deficits require further investigation with duplex ultrasonography or arteriography. ${ }^{3}$ Clinical assessment by a 
vascular surgeon and early radiological or surgical intervention is essential to prevent permanent motor, neurological or tissue damage.

Contributors DK reviewed the patient, acquired the images, selected the case for publication and wrote the manuscript. SP reviewed the patient and performed the operation. He acquired the intraoperative images and he contributed in the drafting and the final revision of the manuscript. IT participated in the treatment of the patient, contributed to the design and reviewed the final manuscript. All authors reviewed and approved the final version.

Competing interests None declared.

Patient consent Obtained.
Provenance and peer review Not commissioned; externally peer reviewed.

(c) BMJ Publishing Group Ltd (unless otherwise stated in the text of the article) 2017. All rights reserved. No commercial use is permitted unless otherwise expressly granted.

\section{REFERENCES}

1 Anderson $\mathrm{CB}$, Etheredge $\mathrm{EE}$, Harter $\mathrm{HR}$, et al. Blood flow measurements in arteriovenous dialysis fistulas. Surgery 1977;81:459-61.

2 Miles AM. Upper limb ischemia after vascular access surgery: differential diagnosis and management. Semin Dial 2000;13:312-5.

3 Leon C, Asif A. Arteriovenous access and hand pain: the distal hypoperfusion ischemic syndrome. Clin J Am Soc Nephrol 2007;2:175-83.

Copyright 2017 BMJ Publishing Group. All rights reserved. For permission to reuse any of this content visit

http://group.bmj.com/group/rights-licensing/permissions.

BMJ Case Report Fellows may re-use this article for personal use and teaching without any further permission.

Become a Fellow of BMJ Case Reports today and you can:

- Submit as many cases as you like

- Enjoy fast sympathetic peer review and rapid publication of accepted articles

Access all the published articles

Re-use any of the published material for personal use and teaching without further permission

For information on Institutional Fellowships contact consortiasales@bmjgroup.com

Visit casereports.bmj.com for more articles like this and to become a Fellow 